\title{
Pilot Review Study on Management Strategies of Constraints in Bread Wheat (Triticum aestivum L.) Production
}

\section{Anbessie DA*}

Ethiopian Institute of Agricultural Research, Kulumsa Agricultural Research Center, Ethiopia

*Corresponding author: Anbessie Debebe Aboye, Ethiopian Institute of Agricultural Research, Kulumsa Agricultural Research Center, Inorganic Soil Fertility Management Research Program, P.O. Box 489, Asella, Ethiopia, Tel: +251911313234; Email: anbessiedebebe@gmail.com

\section{Pilot Study \\ Volume 4 Issue 5}

Received Date: August 03, 2020

Published Date: August 13, 2020

DOI: $10.23880 /$ jenr- 16000210

\section{Abstract}

With the aim of providing an overview of the bread wheat (Triticum aestivum L.) production efficiency and its management requirements such as agro-climatic conditions, aridity, weather of different areas, the soils nutrient character and fertilization status in broad and inclusively in Ethiopia, relating them with existing research tendencies and to show imminent benefits of soil nutrient management studies and their significance for improved agronomic formulations and cultural practices. This paper reviewed that application of balanced nutrients under optimum moisture availability in different soil types is an important crop management strategy, which may help maximizing crop yield and quality. Also, lack of optimum nutrients and moisture in the soil has been the major bottlenecks of bread wheat production and productivity. Bread wheat is a highly valued crop in the national food of Ethiopia and a widely produced crop in the country. Low soil fertility is one of the primary and unescapably constraints to bread wheat production in Ethiopia; thus, there are differences among soil types in yielding ability under different nutrients and soil characteristics. Most smallholder farmers in Ethiopia appreciate the value of fertilizers, but they are not often able to apply them at the recommended rates and at the appropriate time according to the soil characteristics. These are because of high cost, lack of credit, delivery delays, and low and variable returns. In addition, the traditional organic inputs, crop residues and animal manures, identified that it cannot meet crop nutrient demand over large areas because of the limited quantities available, the low nutrient content of the materials, and the high labor demands for processing and application. However, there was felt that could exist an opportunity to increase bread wheat crop yields through identification or selection of soil type and balanced nutrients application or searching for other nutrients sources beyond Urea and Diammonium phosphate especially in Ethiopian condition. Therefore, the integrated use of both the organic and inorganic fertilizers continuum inputs was felt the best option to increase both yield potential and quality of bread wheat crop and environment-friendly sustainable farming systems and increase of profit margins for bread wheat growers. According to the research results of Anbessie, et al. the economic analysis of the experiment was brought to select the best combination of the variety Hidassie/large seed size/ at a plant population rate of 300 plats m$^{-2}\left(142.00 \mathrm{~kg} \mathrm{ha}^{-1}\right)$ gave the greatest grain yield (4070 $\mathrm{kg} \mathrm{ha}^{-1}$ ) with low cost of production and higher net benefits and recommended tentatively as 1 st option for the study area. On the other hand, the variety Hidassie/large seed size/ at a plant population rate of 250 plants $\mathrm{m}^{-2}\left(118 \mathrm{~kg} \mathrm{ha}^{-1}\right)$ gave better yield (3873 $\mathrm{kg} \mathrm{ha}^{-1}$ ) with a slightly additional cost rather than the primarily recommended seed rate and it was recommended as a $2^{\text {nd }}$ option for the small scale farmers of the study area.

Keywords: Wheat Productivity; Benefit Cost; Organic and Inorganic Fertilizers; Production Constraints; Soil and Climate Requirements; Yield and Quality 


\section{Journal of Ecology and Natural Resources}

\section{Introduction}

Bread wheat (Triticum aestivum L.) is the most crucial cereal crop in the world [1-3], and the main source of major food for the populations of Ethiopia. Being the main primary food of rapidly increasing population of Ethiopia, bread wheat occupies dominant position in the agricultural policies of the country [4]. It is grown on more hectares than any other food crop, and is one of the vital sources of nutrients for humans in many areas of the world. Increasing agricultural production efficiency in Ethiopia is a means for both to improve the livelihoods of rural people and the sustainability of the economy as agriculture is the main stay of more than $80 \%$ of the Ethiopian population and accounts for $40 \%$ of the gross domestic product (GDP) of the country [5].

Although Ethiopia has potentially abundant irrigable land and water resources, its agricultural system does not yet fully benefit from irrigated agriculture and the technologies of water management \& land utilization. As a result, agricultural productivity in Ethiopia is very low. The main factor behind this is low uptake of inputs like fertilizers by farmers due to unreliable irrigation accessibility and nutrients deficiency in consequence of low and variable rain fall patterns and land degradation.

Therefore, it is believed that, these production constraints should be reduced using secured access to irrigation and efficient utilization of farming lands. In view of that, expansion of irrigated agriculture and integrated fertilizers utilization are the main focuses of the food security strategy in the growth and transformation plan of the country [6]. It is obvious that bread wheat is one of the main commodity crops known worldwide with respect to its production and economic value which requires good production and management practices. It is used in a variety of products, but its use as flour for bread and baked goods is the most prevalent and without bread wheat baked goods, many of our popular plates would lack the appealability and character that make it preferred. One of the key reasons why bread wheat is best suited for bread making in comparison to other grains is its high gluten content.

However, the quality and high yield of bread wheat production is depending on production and management practices on both field and after harvested. Despite its importance and increased production, bread wheat yield and its quality is affected by various biotic and abiotic stresses, among which low and/or excess mineral nutrition, irrigation schedule or rainfall are among the major ones $[7,8]$. Bread wheat crop has a thin root system and needs optimum and regular application of water and nutrients. Cropping season and soil moisture may affect the quality and yield of field crops any plants; low moisture conditions in the soil are conducive to poor yields [9], while excessive soil moisture results in wastage of irrigation water, nutrients leaching, and may lead to rots and poor seed quality. The crop yields varied considerably among sites and among production seasons at the same site.

These variations were probably due to soil, cropping season, amount and type of nutrients available, planting date degree of plant population and other differences in cultural practices. In dry cropping season, water is the most important limiting factor in agriculture and economic development issues. Water is an important factor in reducing yield and one way to increase the crop yield is using irrigation water; thus, its application must be done efficiently to ensure profitability through maximizing yield, because as a natural resource it is either inadequate or irregular in most areas where somewhat crop production is prevalent [4]. With the adoption of new technology of intensive cropping with high yielding varieties, there is a considerable demand on soil for supply of nutrients. Fertilizer types and/or rates also affect the productivity and quality of bread wheat crop. Weak vegetative growth, poor seed formation, undesirable quality and low nutritional quality result from inadequate levels of the primary nutrients namely: nitrogen, phosphorus, potassium and sulfur [10].

In many crop producing areas lack of available nutrients is frequently one of the most limiting factors due to continuous cultivation of the land and degradation of soils. The average nutrient depletion in East Africa, particularly in Ethiopia is estimated to be around 47 to $88 \mathrm{~kg} / \mathrm{ha}$ per year in general, and $100 \mathrm{~kg} / \mathrm{ha}$ in a year in particular on the highlands [12]. Major factors contributing to such depletion are soil erosion, fixation of $\mathrm{P}$ and leaching of $\mathrm{N}, \mathrm{P}, \mathrm{K}$ and $\mathrm{S}$; the problem is further accelerated by deleterious land use practices resulting from high population pressure. As field crops require and sensitive to a variety of elements for growth and development, the deficiency of these elements is manifested in the detrimental effects on the crop growth and development [12]. Also Mattew, et al. and Havlin, et al. $[13,14]$ stated that Zinc showed high sensitivity in crop production. Thus, this review paper was concentrated more on the identification of different management strategies of constraints in bread wheat production. The remainder of this review study is arranged as follows.

The first section presents an overview of bread wheat production efficiency and its importance, comparing them with current research tendencies and to indicate future benefits of soil nutrient management investigations and their importance for agronomic and cultural practices. The 
Journal of Ecology and Natural Resources

next section begins with important types of bread wheat species and a brief description of the existing institutional arrangements of the bread wheat production status and proceeds by extensive discussions on the structure of bread wheat farms, production and productivity as well as the application of balanced nutrients under optimum moisture availability in different soil types is an important crop management strategy, which may help maximizing bread wheat yield and quality. The consequent sections provide the top bread wheat producing countries of the world with compared to Ethiopia. This information is used to highlight key facts on bread wheat research performance and production constraints in the country. The last section provides conclusions and policy recommendations.

\section{Bread Wheat Production Status in Ethiopia}

Ethiopia is one of the principal producers of wheat in East, Central and Southern Africa. Bread wheat is one of the major cereal crops in the Ethiopian highlands, which range between 6 and $16^{\circ} \mathrm{N}, 35$ and $42^{\circ} \mathrm{E}$, and from 1500 to 2800 $\mathrm{m}$. At present, bread wheat is produced solely under rain fed conditions. It is produced mainly in the southeast, northwest and central parts of Ethiopia. Minor amount is also produced in the rest of the south and northern regions [15]. The two economically important wheat species grown in Ethiopia are tetraploid durum (Triticum Durum) and hexaploid bread wheat (Triticum Aestivum). At the national level presently, $1,664,564.62$ million ha of land is covered by bread \& durum wheat and over 42,192.57 metric tons' coverage produced from this land annually and recently-released bread wheat cultivars are highly responsive to improved management systems relative to older wheat lines [15].

It is produced mainly in the southeast, northwest and central parts of Ethiopia. Minor amount is also produced in the rest of the south and northern regions. The two economically important wheat species grown in Ethiopia are durum wheat (Triticum Durum), tetraploid of which is with a total chromosome numbers of $2 n=28$ ) and which has 4 sets of chromosomes each with a unique genome of $n=7$ chromosomes whereas, bread wheat (Triticum Aestivum), hexaploid of which is with a total chromosome numbers of $2 n=42$ and which has 6 sets of chromosomes each with a unique genome of $n=7$ chromosomes [16]. Its production is increasing rapidly due to both a high local demand, and the availability of high-yielding, input-responsive cultivars adapted to heterogeneous environmental conditions [17]. Area coverage of bread wheat has substantially expanded mainly by replacing unimproved, input non-responsive traditional cereal crops such as teff (Eragrostis Teff), durum wheat (T. Durum) and barley (Hordeumvulgare).

\section{Effect of Varieties and Plant Population on Yields and Grain Quality of Bread Wheat}

According to the research results of Anbessie D [1], the economic analysis using partial budget procedure was performed on grain yield of bread wheat varieties to identify the treatment with the most profitable returns. the economic analysis on grain yield of bread wheat varieties was brought to select the best combination of the variety Hidassie/large seed size/ at a plant population rate of 300 seeds $\mathrm{m}^{-2}(142.00$ $\mathrm{kg} \mathrm{ha}^{-1}$ ) gave the greatest grain yield (4070 $\mathrm{kg} \mathrm{ha}^{-1}$ ) with low cost of production and higher net benefits and can be recommended tentatively as a $1^{\text {st }}$ option for the study area. On the other hand, the variety Hidassie/large seed size/ at a plant population rate of 250 seeds $\mathrm{m}^{-2}$ (118 $\mathrm{kg} \mathrm{ha}^{-1}$ ) gave better yield (3873 $\mathrm{kg} \mathrm{ha}^{-1}$ ) with a slightly additional cost rather than the primarily recommended seed rate and can be recommended as a $2^{\text {nd }}$ option for the small scale farmers of the study area.

The beneficial marginal rate of return (795\%) and benefit cost ratio (7.57) was obtained from the variety Hidassie at a plant populations of 300 seeds $\mathrm{m}^{-2}$ followed by a marginal rate of return $(899 \%)$ and benefit cost ratio (7.55) were also recorded again from the variety Hidassie at plant populations of 250 seeds $\mathrm{m}^{-2}$. So the most cost-effective variety and plant population level for farmers with low cost of production and higher benefits were identified to be the variety Hidassie at a plant population of 300 seeds $\mathrm{m}^{-2}$ in the rain fed cropping season is identified as low cost of production with highest benefit and recommended as $1^{\text {st }}$ option for the producers of wheat crop. The plant populations of 250 seeds $\mathrm{m}^{-2}$ for variety Hidassie/large seed size/ were also cost-effective with highest net-benefit and recommended as $2^{\text {nd }}$ option [1].

\section{Importance of Bread Wheat to Food and Nutrition Security}

Bread wheat (Triticum aestivum L.) is not only the most important cereal crop in the world but also the major source of staple food for the peoples $[3,18]$. Despite of being grown on larger area, average yield at farmers' fields is still far below than the potential [19]. Traditional method of seedbed preparation for preceding crops, late planting, high weeds infestation, water shortage at critical growth stages and nonjudicious use of fertilizers reduce the wheat productivity.

The major role of mineral fertilizers is to improve crop yields but the main constraint in achieving proven crop potential is low use of fertilizers particularly that of $\mathrm{P}$ and $\mathrm{S}$ as compared to $\mathrm{N}[20]$. Bread wheat is widely consumed, in the countries to meet the consumers demand for bread 


\section{Journal of Ecology and Natural Resources}

and other food products. This indicated that globally there is number of people who rely on bread wheat for a substantial part of their diet amounts to several billions. Statistics for the total volume of bread wheat which is consumed directly by humans as opposed to feeding livestock, for the United Kingdom indicates about one-third of the total production, approximately $5.7 \mathrm{~m}$ tones per annum are milled with home production [21].

Globally there is no doubt that the number of people who rely on bread wheat for a substantial part of their diet amounts to several billions. The high content of starch, about $60-70 \%$ of the whole grain and $65-75 \%$ of white flour, means that bread wheat is often considered to be little more than a source of calories, and this is certainly true for animal feed production, with high-yielding, low-protein feed varieties being supplemented by other protein-rich crops, notably soybeans and oilseed residues. However, despite its relatively low protein content, usually $8-15 \%$ bread wheat still provides as much protein for human. Therefore, the nutritional importance of bread wheat proteins should not be underestimated, particularly in less developed countries where bread, noodles \& other products (e.g. burger, cookies, baby biscuit etc.) may provide a substantial proportion of the diet [21]. In general, bread wheat is the most widely used cereal for bread and bakery production process throughout the whole world $[22,23]$.

It is grown in nearly every region of the world and represents a main source of food and income for millions of smallholder farmers. Pena-Bautista RJ, et al. [24] reported that, bread wheat-based foods are critical for food security and nutritional security worldwide. The global bread wheat researchers draw attention to the predicted upcoming food crisis, as populations in developing countries expand rapidly, especially in Africa and South Asia. They note that population growth is likely to overtake yield gains in bread wheat and call for larger investments in bread wheat and other cereal crops to keep pace with future demand.

Originating in the Fertile Crescent about 10,000 years ago, bread wheat is currently the most widely grown crop, and after rice's the $2^{\text {nd }}$ most important food crop in the developing countries. Bread wheat provides about $19 \%$ of the calories and $21 \%$ of protein needs of daily human requirements at the global level [25]. Bread wheat has played a fundamental role in human civilization and has contributed to improving food security at global and regional levels. Some have argued that the price hikes in bread wheat in 2008 contributed to the political instability in a few regions in the world where bread wheat is a staple crop, including the recent unfortunate development in some Arab countries [26]. Cultivated wheat is classified into two major types; the hexaploid bread wheat $(2 \mathrm{n}=6 \mathrm{x}=42, \mathrm{AABBDD})$ and the tetraploid durum wheat $(2 \mathrm{n}$ $=4 \mathrm{x}=28, \mathrm{AABB})$.

Currently, at the global level, bread wheat accounts for $95 \%$ of all the wheat produced. Based on growth habit, wheat is classified into spring wheat and facultative/winter wheat, covering about 65 and $35 \%$ of the total global wheat production area, respectively Braun [25], Braun and Saulescu [27]. The flour of bread wheat is used to make French bread, Arabic bread, Chapati, biscuits, pastry products and for the production of commercial starch and gluten.

\section{Important Types of Wheat Species}

Wheat was domesticated in the Near East at least 9,000 years ago. It originated through hybridization and polyploidy of several species of the genus Triticum, all with a basic chromosome number of $7(n=7)$. Some species of Triticum are cultivated and some are non-cultivated, or rarely cultivated. The wild species of wheat can still be found in northern Iraq, Iran, and Turkey. The most important new Triticum species and subspecies are described under the following sections. Six classes bring order to the thousands of varieties of wheat. They are: hard red winter (HRW), hard red spring (HRS), soft red winter (SRW), hard white (HW), soft white (SW) and durum. Bread wheat is hexaploid species, with $2 n=42$ chromosomes that are derived from three wild families 'ABD', each with a unique genome of $n=7$ chromosomes. The genome of wheat is designated to signify the genetic sources of its 21 pairs of chromosomes. Durum wheat is a tetraploid species, with $2 n=28$ chromosomes derived from two genomes 'AB'. It is widely grown in the northern US, Canada, southern Europe, and parts of India. Due to its high protein content, it is the preferred type of wheat for making spaghetti, macaroni, and noodles or a strip of pasta [16].

\section{Top Wheat Producing Countries of the World in Compared to Ethiopia}

Wheat is one of the most important crops to humankind as it is a staple of many diets around the world. According to FAOSTAT, China produces more wheat than any other country, followed by India, Russia, and the United States. So far Ethiopia produces very less wheat production than any other country. Here is an overview of the world's top ten wheat-producing countries as compared to Ethiopian wheat production. 


\begin{tabular}{|c|c|c|}
\hline Rank & Country & Wheat Production (Tones) \\
\hline $\mathbf{1}$ & China & $13,43,40,630$ \\
\hline $\mathbf{2}$ & India & $9,85,10,000$ \\
\hline $\mathbf{3}$ & Russian Federation & $8,58,63,132$ \\
\hline $\mathbf{4}$ & United States of America & $4,73,70,880$ \\
\hline $\mathbf{5}$ & France & $3,69,24,938$ \\
\hline $\mathbf{6}$ & Australia & $3,18,18,744$ \\
\hline $\mathbf{7}$ & Canada & $2,99,84,200$ \\
\hline $\mathbf{8}$ & Pakistan & $2,66,74,000$ \\
\hline $\mathbf{9}$ & Ukraine & $2,62,08,980$ \\
\hline $\mathbf{1 0}$ & Germany & $2,44,81,600$ \\
\hline & Ethiopia* & $\mathbf{1 5 , 7 1 , 0 0 0}$ \\
\hline
\end{tabular}

Source: Data from FAOSTAT http:// faostat.fao.org/site/567/DesktopDefault.aspx (2011) [28].

Table 1: The World's Top Ten Wheat-Producing Countries as Compared to Ethiopian Wheat Production*.

\section{Brad Wheat Producers and their Productive Efficiency in Ethiopia}

Ethiopian agriculture is occupied by smallholders. As of 2014, close to 5 million farmers engage in bread wheat production in Ethiopia. This is about a third of all smallholder farmers in the country [29]. Even though there are an enormous number of farmers, Ethiopian farmers in general cultivate small lands per acreage. Above half of the smallholders cultivate farms less than a hectare [30]. The average farm size has also declined over time. Official statistics, for instance, indicate that over the past five years alone (2009/10-2013/14) the proportion of smallholders who cultivate farms less than a hectare has increased by 5.2 percent while those who cultivate farmland that vary between 1 and 2 hectares and over 2 hectares declined by 5.4 and 7.1 percent, respectively.

The average wheat farmland in 2014 was only 0.34 hectares, and varies between 0.28 and 0.39 hectares. Despite such miniature plot sizes, there is high degree of inequality in access to farmlands. Below, 57 percent of smallholder farmers cultivate only 20 percent of cultivated farmlands, whereas 46 percent of cultivated farmlands are operated only by 17 percent of farming households. Although smallscale farmers dominate wheat production in Ethiopia, there are some large-scale commercial farms that grow wheat. However, large commercial bread wheat producers account only 3 to 5 percent of all wheat cultivated land [31].

Wheat is the fourth largest cereal crop produced in Ethiopia [32]. Production of wheat has significantly increased over the past 20 years. It has increased from 890000 metric tons (MT) in the 1991/92 marketing year to 3.11 million MT in 2009/10 Bergh [33] and to 4.04 million MT in 2014/15 Growth in wheat production has, however, been characterized by significant annual fluctuations, primarily due to variations in rainfall. The coefficient of variation of bread wheat production during the 1996-2013 periods was 44 percent, whereas the Cuddy-Della Valle index is 12 percent. The latter index implies that bread wheat production deviates from the trend wheat growth by an average of 12 percent.

On the other hand, the proportion of cereal area cultivated with wheat has fluctuated between 15 and 18 percent over the past ten years with no discernible trend [31]. This implies that other cereals have expanded their cultivated areas at similar rates over the past 20 years. Bread wheat yield has increased over the past decade. Recent estimates show that bread wheat farmers in Ethiopia produce on average 2.5t/ ha. There is significant variation in average bread wheat yields through regions and zones. For instance, the average bread wheat yields in some zones of Oromia and Southern Nations \& Nationalities People (SNNP) regions of Ethiopia, where farm sizes are relatively large, were between 2.5 and $2.8 \mathrm{t} / \mathrm{ha}$, whereas, average yields are reportedly lower than the national average in most of parts of Amhara and Tigray regions of Ethiopia, ranging between 1.7 and $1.9 \mathrm{t} / \mathrm{ha}$, which is well below the experimental yield of above $5 \mathrm{t} / \mathrm{ha}$. There is, however, consistent progress in terms of narrowing this yield gap between field and experimental levels.

As indicated by official statistics, wheat yield has doubled over the past two decades. In comparison to the global trend the recent growth in wheat yield in Ethiopia is also encouraging. Considering wheat, Ethiopia has managed to more than double its land productivity over the past one and 


\section{Journal of Ecology and Natural Resources}

half decades. The second best performer in the category is Malawi, a country that hugely subsidizes its fertilizer market. Ethiopia is among the top bread wheat producer countries in Africa, following South Africa and Egypt. However, bread wheat yield in Ethiopia is only 70 percent of the level in South Africa, and only 39 percent of the highly irrigated wheat production system of Egypt. Compared to China, wheat yield in Ethiopia (in 2014) is about half of that of China.

Typically bread wheat yield in Ethiopia needs to be improved further to level-up with Africa's and world average wheat yields, which were 13 and 32 percent higher than the average wheat yield in Ethiopia, respectively FAO 2015a [32]. A study by FAO, however, shows that Ethiopia (in 2012) ranks $80^{\text {th }}$ in wheat yield globally. Wheat yield in Ethiopia in 2012 was only 25 percent of that of New Zealand, which leads the global performance with 8.92 tons per hectare. Compared to the best performing African countries such as Namibia and Zambia, wheat yield in Ethiopia was only about one-third of these countries. Beyond agro-climatic and political factors contributing to lower yields, technology could play a more dominant role in productivity, enabling Ethiopia to enhance its yields and achieve at least a sufficient yield to feed and change the living standard of its growing population [34].

\section{Climate \& Soil Requirements of Bread Wheat Crop}

Bread wheat is the most widely cultivated crop species in Ethiopia and it has a wide range of climatic and soil adaptation. Ethiopia is the largest wheat producer in the Sub-Saharan Africa with about 0.75 million ha of durum and bread wheat. Wheat is one of the major cereal crops in the Ethiopian highlands, which range between 6 and 16 $\mathrm{N}, 35$ and $42 \mathrm{E}$, and from $1500 \mathrm{~m}$ to $28 \mathrm{~m}$ [35]. At present, wheat is produced solely under rain fed conditions. About 60 percent of wheat area is covered by durum and 40 percent by bread wheat. Of the current total wheat production area 75.5 percent is located in Arsi, Bale, and Showa regions of Ethiopia.

Six percent of the 13 million ha classified as highly suitable for wheat production is located in Arsi, Bale, and Showa regions of Ethiopia. Altitude plays an important role in the distribution of wheat production through its influence on rainfall, temperature, and diseases. In Arsi, Bale, and Showa regions of Ethiopia, the soil, moisture and disease conditions in the $1900-2300 \mathrm{~m}$ altitude zone are favorable for the production of early- and intermediate- maturing varieties of bread wheat. This is estimated to comprise 25 percent of the total wheat area, while the remaining 75 percent falls in the 2300-2700 m zone. There, early-, intermediate - and late varieties are grown. Soil types used for wheat production vary from well-drained fertile soils to water logged heavy
Vertisols [35].

\section{An Agro-Climatological Characterization of Bread Wheat Production Areas in Ethiopia}

Ethiopia is the second largest producer of wheat in subSaharan Africa, following South Africa. About 900,000 ha of bread (Triticum aestivum) and durum (T. turgidum var. durum) wheat's are grown in Ethiopia, primarily as highland rain fed crops. At the national level presently, 1,664,564.62 million ha of land is covered by bread \& durum wheat and over 42,192.57 metric tons' coverage produced from this land annually and recently-released bread wheat cultivars are highly responsive to improved management systems relative to older wheat lines (MoANR, 2016). Mean wheat yields are around $1.4 \mathrm{t} / \mathrm{ha}$, well below experimental yields of over $5 \mathrm{t} /$ ha [36]. Ethiopia's current annual wheat production of approximately 1.7 million tons is insufficient to meet domestic needs, forcing the country to import 30 to $50 \%$ of the annual wheat grain required. The yield gap of over 3 tones/ha suggests the potential for increasing production through improved crop management, particularly increased use of fertilizers.

However, there is also justification for examining whether wheat production can be introduced to nontraditional areas. Geographic information systems (GIS) provide a way to do this, allowing researchers to examine crop distribution in relation to climate and other factors. This review paper first examines the current distribution of wheat production in relation to climate. It then uses the described climatic limits as the basis for evaluating the potential for increasing wheat production area in Ethiopia.

To understand the possible contribution that different research centers might make to improving wheat production in current or potential wheat areas, climate similarity analyses were conducted for research stations used by the cooperative National Wheat Research Program coordinated under the auspices of the Ethiopian Agricultural Research Organization (EARO). Emphasis is given to the use of quantitative characterizations based on climate data that have been interpolated over all of Africa [37]. This ensures that mapped distributions are more fully testable and reproducible, thus contributing to a more precise understanding of the adaptation of wheat in Ethiopia as well as in other countries.

\section{Nutrient Requirements of Bread Wheat Crop}

A sustainable agricultural system is one that is economically viable, provides safe, nutritious food, and 


\section{Journal of Ecology and Natural Resources}

conserves resources and enhances the environment [38]. Fertilizers are the basis to produce more crop output from existing land under cultivation. The economic and environmental implications of excessive nutrient use by crops calls for balanced fertilization and those nutrient needs of crops are according to their physiological requirements and expected yields [39].

Fertilizer requirements of bread wheat crop vary with fertility status of the soil, availability of soil moisture, variety of the crop, purpose for which the crop is grown, etc. Of many factors, fertility status of the soils significantly affecting bread wheat crop yield. The three major essential plant nutrients, $\mathrm{N}, \mathrm{P}$ and $\mathrm{K}$ are increasingly in short supply in the soils of many African countries because of the large quantities taken up from the soil relative to the other essential nutrients [4042], which is true also for many Ethiopian soils [43]. Soil fertility studies conducted at different locations in Ethiopia for different crops have shown significant yield responses to applied nitrogen and phosphorus fertilizers, indicating that most of the Ethiopian soils are deficient in nutrients, especially $\mathrm{N}$ and $\mathrm{P}$ [43-45].

Nitrogen performs many vital functions in the wheat plant. Wheat requires 0.91 to $1.13 \mathrm{~kg}$ of nitrogen $(\mathrm{N})$ per 1 liter of grain, or, if grazed, 0.454 pound per acre or each 1.361 kg-per-acre animal gain. Shortages of $\mathrm{N}$ may cause reduced tillering, reduction in head size, poor grain fill and low protein content. Adequate $\mathrm{N}$ must be available to the wheat plant at all phases of development. Splitting $N$ applications generally improves use efficiency, minimizes risk to investment and safeguards the environment. Growers should make their top-dressing applications early, prior to joining, to maximize production efficiency. Timing, placement and nitrogen source should be managed to fit climatic conditions, soil type and tillage system.

\section{Phosphorus in Wheat Production}

Fertilizer and crop prices are at much higher levels than in recent years. Adequate phosphorus (P) fertility is associated with increased tillering and grain head numbers, reduced winter-killing, maximum water-use efficiency, hastened maturity, and lower grain moisture at harvest. Winter wheat requires about 0.6 to $0.7 \mathrm{l}$ pounds of phosphorus pentoxide $\left(\mathrm{P}_{2} \mathrm{O}_{5}\right)$ per bushel grain. Because $\mathrm{P}$ is relatively immobile in soils, banded or starter applications are often most effective in soils testing low to medium. Even in high-testing soils, starter applications help plants establish more quickly. Banded $\mathrm{P}$ also helps young plants overcome the adverse effects of soil acidity. Broadcast $\mathrm{P}$ should be incorporated to improve positional availability. Finally, remember that adequate $\mathrm{P}$ increases $\mathrm{N}$ recovery and use efficiency. The effect of balanced fertility and its impact on nutrient use efficiency is especially important in today's environment.

\section{Potassium in Wheat Production}

Potassium $(\mathrm{K})$ in wheat production is associated with increased moisture and $\mathrm{N}$ use efficiency, and decreased incidence of disease and lodging. The requirement for $(\mathrm{K})$ is approximately equal to that of $\mathrm{N}$. Placement of $\mathrm{K}$ is not as critical as $\mathrm{P}$ since it's more mobile in soils. Split applications should be made on deep sandy soils in high- rainfall areas to increase use efficiency. Don't overlook the importance of secondary and micronutrients on wheat. For example, sulfur deficiency creates problems in some areas. Base your applications of these nutrients on field history, soil tests and plant analysis. Profitable and efficient wheat production involves supplying adequate amounts of plant nutrients when and where the crop needs them. Fertilizer application rates are of little value if nutrients aren't in the proper place at the proper time. Effective fertility management strategies vary from region to region, but a characteristic of all good soil fertility management programs is early planning.

Crops have a moderate to high fertilizer requirement, depending on the nutrient status of the soil [45]. Today, efforts to obtain higher yields of bread wheat have led to the application of various types of fertilizers. The different types of fertilizers have dissimilar concentrations of plant nutrients and therefore affect the soil environment differently. As humankind strives to obtain higher yields of bread wheat through heavy application of fertilizers, such procedures must equally preserve the quality of the crop [46]. Crops are a heavy feeder, requiring ample supplies of $\mathrm{N}, \mathrm{P}$, and $\mathrm{K}$ in either the form of inorganic or organic fertilizers or a combination of them. Sub-optimal levels of these nutrients in the soil adversely affect the yield, quality and storability of bulbs [47].

\section{The Use of Mineral Fertilizers in Bread Wheat Production}

Nitrogen $(\mathrm{N})$ is a vitally important raw material required for the growth of plants, as it is an essential constituent of metabolically active compounds such as amino acids, proteins, enzymes, coenzymes and some non-proteinous compounds [48]. On the other hand, extensive use of N-based fertilizers worldwide has resulted insignificant environmental problems associated with high input agricultural production systems. The pollution of natural resources and rising costs of $\mathrm{N}$ fertilizers has also focused greater attention to improve their use in agriculture and created the development of improved $N$ use efficient crop plants [49,50].

On the other hand, smallholder farmers in Ethiopia are known to use low rates of inorganic nitrogen and phosphorus 
fertilizers (less than $100 \mathrm{~kg} / \mathrm{ha}$ of urea and/or DAP) for crop production due to prohibitively high prices [51-53]. The low application of inorganic fertilizers to crops may stem from reluctance of farmers to apply fertilizers due to anticipated low response of the crop because of climatic uncertainty (particularly erratic rainfall) during the main growing season [51]. It may also be attributed to lack of knowledge as to which kinds and rates of fertilizers are recommended for their specific crops, soils, and agro-climatic conditions [54]; or to existence of disparities in access to fertilizers or purchasing power among farmers as a result of varied resource endowments [55,51].

Farmers apply also low amounts of organic fertilizers owing to competing needs such as the use of cow dung as a source of energy for cooking and crop residues as feed for animals [51]. The total amount of $\mathrm{N}$ required for crops will vary with the soil type, the previous crop grown, and the amount of organic matter present in the soil and the climatic conditions during the growing season. Kakar, et al. [56] reported that $\mathrm{N}$ accounts for a higher percentage of the variation in plant height, leaf area, leaf count, and fresh and dry plant mass when it was increased from 50 to $200 \mathrm{~kg} / \mathrm{ha}$. Bread wheat will generally require $70-125 \mathrm{~kg} \mathrm{~N} / \mathrm{ha}$ and one half of it should be applied as soon as the crop begins to grow; the remainder should be split into two to three applications at three-week intervals and should be completed within 4-6 weeks [57].

The production of large seeds of wheat varieties and vigorous seedlings is one of the most important factors of successful crop production [58,1]. Adequate application of $\mathrm{N}$ during seedling stage and application of different sources and rates of $\mathrm{N}$ play an important role in the production of vigorous seedlings and optimum tillers expansions [59]. Excessive application of $\mathrm{N}$ at a late seedlings stage of wheat crop can limit yields, while inadequate $\mathrm{N}$ can hasten maturity and limit yield [60]. It is best not to apply $\mathrm{N}$ when the seedlings are beginning to enlarge since it will encourage excessive leaf growth and reduce seed size [61].

Nitrogen and phosphorus are among the most important and frequently applied nutrients as mineral fertilizers for producing most crops in Ethiopia. However, the rates of application of the nutrients are far less than the requirements and based on blanket recommendations on different areas and soils [62]. However, the crop nutrient requirements vary with species, variety, soil type and season, a blanket recommendation of $92 \mathrm{~kg} / \mathrm{ha} \mathrm{N}$ and $\mathrm{P}_{2} \mathrm{O}_{5}$ each of $\mathrm{N}$ and $\mathrm{P}$ fertilizer are in using for bread wheat production in many areas of Ethiopia. Kilgori [63] reported similarly a significantly increased yield of bread wheat with increased $\mathrm{N}$ from 0 to 60 and $120 \mathrm{~kg} / \mathrm{ha}$.
However, they found that higher dosage of 180 and 240 $\mathrm{kg} \mathrm{N} /$ ha reduced the yield. At Samaru (Nigeria), Babaji [64] observed that $\mathrm{N}$ application increased almost all growth and yield parameters of bread wheat significantly with a maximum yield of $15 \mathrm{t} / \mathrm{ha}$ at $90 \mathrm{~kg} \mathrm{~N} / \mathrm{ha}$. Phosphorus deficiency is one of the largest constraints to crop production in many tropical soils, owing to low native contents and high P fixation capacity of the soil [65-67]. Phosphorus is essential for root development and when the availability is limited, the growth of plant can be reduced.

It is involved in several physiological and biochemical processes in plant maturity, fruit setting and seed production [68].

It is part of plant nucleoprotein and hence important in plant heredity and also plays a role in cell division, stimulates root growth, and hastens plant maturity and physiologically notable in the storage and transfer bonds of ATP. The need for $\mathrm{P}$ is critical during the early stage of growth when normal meristem development and rapid height growth are necessary for a high yield. The movement of $\mathrm{P}$ in soils is very low and its uptake generally depends on the concentration gradient and diffusion in the soil near roots [69]. $P$ deficiencies reduce root and leaf growth, seed size and yield and can delay maturation [70]. In soils that are moderately low in P, bread wheat growth \& yield can be enhanced by applied P. Results of long-term fertilizer trials on loamy sand soils in Germany have shown a strong response of crop to $P$ fertilization in the range $0-52 \mathrm{~kg} \mathrm{P} / \mathrm{ha}$. [71]. Depending on yield levels, $\mathrm{P}$ uptake rates estimated to be about $15-30 \mathrm{~kg} / \mathrm{ha}[72,73]$. In western Kenya, as reported by Jamma [74] soil, water and nutrient losses tremendously reduced by $\mathrm{P}$ addition because of the rapid formation of soil cover.

Application of P from 29 to $48 \mathrm{~kg} \mathrm{P} /$ ha can usually be adequate for better wheat production while in the desert areas, however, rates of $\mathrm{P}$ up to $96 \mathrm{~kg} \mathrm{P} /$ ha needed [75]. Crop production could be highly profitable, if the correct amount and type of fertilizer is applied and the crop species grown utilizes the fertilizer nutrients very efficiently [20]. Application of phosphoric fertilizers generally has a great impact on crop yields because $P$ deficiency limits the response of plants to other nutrients, especially on highly weathered and leached soils of both tropical and temperate regions of the world where soil acidity causes infertility and general limitation to crop production [76].

Beside $P$ fertilizer management, soil type could significantly determine the efficiency of $\mathrm{P}$ use by specific crop species [77]. Best quality wheat can be produced through application of balanced fertilizers [46]. Research work has been done on the base of NP in different soil 


\section{Journal of Ecology and Natural Resources}

types Brewster [78]; Lemma and Herath [79] and in various climatic conditions, but very limited work has been reported on various sources of fertilizers for a certain nutrient. Among the major macronutrients, potassium $(\mathrm{K})$ and sulphur $(\mathrm{S})$ have been ignored by most of our local growers to apply to their crops $[45,43]$.

Though the quantity of $\mathrm{K}$ and $\mathrm{S}$ in most of the soils is adequate, there is also evidence of fixation of $\mathrm{K}$ and leaching of $S$ in different types of soils [80]. Therefore, the application of $\mathrm{K}$ and $\mathrm{S}$ to soils having even medium amounts of $\mathrm{K}$ and $\mathrm{S}$ contents may still show positive effects on plants [58]. In addition, balanced application of nutrients can improve soil fertility and eliminate the effect of nutrient deficiencies beyond improving of wheat productivity and quality [81].

Similarly, Mineral fertilizers of balanced doses increased the leaf area, photosynthetic productivity, yield of plants in particular, and resulted in substantial increases in crop production in general [82]. Like other macronutrients, sulphur is a vital nutrient for life and essential for plant growth. It contributes to high crop yields and quality in three different ways:

1) It provides a direct nutritive value;

2) It improves the use efficiency of other essential plant nutrients, particularly $\mathrm{N}, \mathrm{P}$ and some micronutrients, like $\mathrm{Zn}, \mathrm{Fe}, \mathrm{Cu}, \mathrm{Mn}$ and $\mathrm{B}$; and

3) It improves crop product quality by increasing protein and oil percentage in seeds, cereal quality for milling and baking, nutritional value and marketability of vegetables and fruits.

In general, $\mathrm{S}$ has similar functions in plant growth and nutrition as $\mathrm{N}$ and plant requirements for $\mathrm{S}$ are comparable to P. Most crops remove 15 to $25 \mathrm{~kg} \mathrm{~S} / \mathrm{ha}$. Cereal crops, oil crops, legumes, forages, and some vegetables require more $\mathrm{S}$ than $\mathrm{P}$ for optimal yield and quality [83]. Significant increases remained restricted up to $30 \mathrm{~kg} \mathrm{~S} / \mathrm{ha}$ even though application up to $45 \mathrm{~kg} \mathrm{~S} /$ ha consistently increase yield of crops [84]. Surendra [85] also reported an increase being sulphur loving crop, sulphur response in bread wheat is natural and expected.

\section{Integrated use of Organic and Inorganic Fertilizers}

The use of balanced sources of nutrients to obtain high yield and good quality bread wheat is an important practice in today's bread wheat production. Organic inputs are often proposed as alternatives to mineral fertilizers. However, the farmers' organic inputs, crop residues and animal manures cannot meet crop nutrient demand over large areas because of the limited quantities available, the low nutrient content of the materials, and the high labor demands for processing and application. Therefore, most farmers in Africa fall within the two extremes of the organic to inorganic fertilizer continuum and use a combination of organic and inorganic inputs [86]. Balancing use of chemical fertilizers and organic manures has assumed great importance nowadays to maintain as well as sustain a higher level of soil fertility and crop productivity [87].

Farmyard manure (FYM) is among the important soil amendments to which farmer's access has in mixed farming systems as it improves both crop productivity, and the physical and chemical conditions of soils through supplying different nutrients and organic matter $[88,89]$. The widespread use of FYM greatly depends, among others, on proper application methods, which increase the value, reduce costs, and enhance effectiveness [90]. Manures and composts rich in potash like wood ash and poultry manure giving an increased outturn Well-rotted FYM is applied at the rate of 25-50 t/ha after the first ploughing or it may preferably be applied to the preceding crop [91]. Both manure and chemical fertilizers have a potential role on the growth and development of crops [87]. The application of FYM at the rate of $20 \mathrm{t} / \mathrm{ha}$ increased wheat yield significantly with increased uptake of $\mathrm{N}, \mathrm{P}$ and $\mathrm{K}$ nutrients; the S and FYM application showed synergistic interaction effect on the uptake of $S$ and ultimately on the yield of wheat; maximum yield was obtained at $40 \mathrm{~kg} \mathrm{~S} / \mathrm{ha}$ with 20 t FYM/ha [88]. In Ethiopia, Fisseha [92] reported application of $20 \mathrm{t} / \mathrm{ha}$ of biogas sludge and $20 \mathrm{t}$ FYM/ha to be the optimum level in increasing the seed size and weight of wheat grains.

\section{Effect of Pre-Harvest Factors on Postharvest Quality and Storage Life of Bread Wheat Crop}

Many external and internal factors influence both postharvest quality and storage life of crops. According to Baligar, et al. [93] external factors such as soil moisture, temperature, light, management practices, soil biological, and fertilizer materials, and their interactions with genetic, morphological, and physiological plant traits have profound effects on yield and qualities of crops. A dry matter or total solids content is an important quality factor in many crops. Dry matter measurements also provide information on environmental factors and cultural management procedures during the production season [94].

Bread wheat grains are routinely stored for varying lengths of time before being marketed. Even though the crop grains may be dormant during this time, viability and seed quality changes have been measured in and its pungency was found to play a very important role in the storage of crop grains [95]. Flavor intensity and quality do change in storage 


\section{Journal of Ecology and Natural Resources}

and the changes appear to be dependent on cultivar, storage duration, depth of seed dormancy, and storage temperature. Jones and Bisson [96] reported that mild, high moisture (low solids) had lower storage quality than pungent, low moisture (high solids) seeds. Other important causes of quality loss are sprouting and rooting, which occur because of high humidity conditions in soft packaging and because of storage at higher than the recommended $0-2^{\circ} \mathrm{C}$ [97].

Post-Harvest Handling and Seed Storage Conditions of bread wheat crop, especially untreated ones need good handling and storage conditions after harvesting. In this regard, Bread wheat seeds or grains are damaged in their quality otherwise preserving of seeds should take place as it serves several functions. First, it dries the outer two to four scales providing mechanical protection, limit entry of rot-causing organisms into still fleshy pseudo stems or injured tissues, limit gas exchange; both effluent and intake of moisture, oxygen and carbon dioxide and giving an attractive appearance. Lastly, drying encourages dehydration and sealing of wounds that may have occurred during seed growth or mechanical damage.

All these are to bring down the metabolism of the bread wheat seeds and promote mechanical damage dormancy [98]. Bread wheat, which is not being sold total harvest, needs to be dried prior to storing. Careful drying and prior to storage are crucial to prevent losses due to emergent or sprouting damages. In addition, careful handling and the choice of a suitable storage method for the cultivar type in question are vital to ensure that the product retains its quality until it reaches the consumer.

At small scale level, cold room and aired storage structures, ventilated roofing oriented to the direction of prevailing wind, can effectively be used for extending the storage life of seeds. The most important consideration here is that bread wheat should be thoroughly matured, dried before storage. The essentials of successful storage are through ventilation, a uniform and comparatively low temperature, low humidity, proper maturity and freedom from disease infection. The climatic conditions of the storage area also influence the seeds life in storage [11].

Bread wheat respiration rate are generally low, but related exponentially to increased storage temperature between 0 and $20^{\circ} \mathrm{C}$ and is generally a good indication of postharvest quality degradation. Relative humidity has a large influence on storage life; sometimes its influence is greater than that of temperature. For long storage time, the optimum range of relative humidity is $50-60 \%$ and favorable temperature ranges from 0 to $5^{\circ} \mathrm{C}$, which can be stored for 6-9 months depending on cultivar and species. They also must have good air circulation such as an open ventilators and conditioners, but refrigerator-storing causes loses of flavor very quickly and are subject to sprouting, due to the cool temperature and higher humidity [99]. Forms and purposes of seeds storage also determine the quality and storage life of crops [100].

\section{Irrigation to Maximize Water Productivity}

With water scarcity increasing, it is vital that water be more wisely used in irrigating bread wheat. In many bread wheat growing areas water became the most limiting input to production. Maximizing water productivity aims at improving production, and achieves higher food security [11]. Research's at ICARDA shows that deficit irrigation of brad wheat can save $20-30 \%$ of the water, with only $5-10 \%$ reduction in yield. As land is not the most limiting natural resource, the saved water can be applied to new land with much higher production than the reduced yield associated with deficit irrigation. This is maximizing water productivity instead of land productivity. More gains can be achieved with deficit supplemental irrigation of rainfed wheat as indicated earlier. Other ways to improve water productivity is to suppress evaporation from soil surface by minimizing soil wetting and fast crop cover. Providing balanced nutrition and control of pests and diseases improves water productivity.

\section{Nutrient Requirements of Wheat Crop}

Sustainable agricultural system is one that is economically viable, offers nontoxic, nutritious food, and preserves resources and improves the environment [38]. Fertilizers are the fundamentals to produce more crop yields from the existing farming lands. The economic and conservational significances of the uncertain nutrients usage by crops calls for nontoxic fertilization and that nutrient needs of crops is in keeping with their physiological requirements and predictable yields [39]. Fertilizer needs of crops differ with fertility status of the soil, obtainability of soil moisture, variety of the crop, persistence for which the crop is grown, etc. of several reasons, fertility status of the soils significantly affecting crops yield. Various rates and types of isolates of rhizobia and their benefit have been presumed beneficial in regard to soil resource improvement and increase yield and yield components [101].

Modern agriculture wiped out its sustainability owing to excess use of chemical fertilizers and dangerous pesticides further leading to higher cost of farming, declined food security and welfare, and finally the decline in soil Fertility [102]. Organic nitrogen fixation is a central life supportive process that provides most of the fixed nitrogen required to sustain life. Animals, including humans, depend on plants to supply a great deal of the energy and nitrogenous compounds required for survival. Plants are similarly reliant 
on the availability of nitrogenous combinations formed from atmospheric $\mathrm{N}_{2}$ either commercially or biologically by microbes. In this way, nitrogen fixation assumes significant importance in agriculture for the reason that good crop yields depend on an ample supply of fixed nitrogen by which the biological process gives about $65 \%$ of the total annual yield of fixed nitrogen $[103,101,1]$.

\section{Economic Analysis of Bread Wheat Grain Yields}

The Economic analysis results have been indicated a consistent profitable response on grain yield of bread wheat. Relating to the partial budget analysis results, the highest net benefit value (46735 ETB ha-1) was obtained from the variety Hidassie at a seed rate of 300 seeds $\mathrm{m}^{-2}$, followed by the net benefit value (44460 ETB ha-1) was obtained from the variety Hidassie at a seed rate of 250 seeds $\mathrm{m}^{-2}$ and the lowest grain yield (30117 ETB ha ${ }^{-1}$ ) was obtained from the variety Hidassie at seed rate of 400 seeds $\mathrm{m}^{-2}$. The results of the partial budget analysis and the economic data used in the development of the partial budget are illustrated in [1].

\section{Partial Budgeting Analysis of Bread Wheat Grain Yields}

In order to organize the experimental data and information about the costs and benefits of various alternative treatments, a partial budget analysis was done to determine the economic impact of various alternative treatments as compared to the farmers' practice for bread wheat production at the study area. Local market (LM) price was used to calculate the product value. The cost of labor for weeding was taken at 35.00 ETB per day. Considering the costs that varied (cost of seed, fertilizers, chemicals and labor wage for planting, weeding and harvesting), the farmers' practice had a lower cost than the experimental method [104-106].

In the partial budgeting analysis result of the present study, the costs for the different plant population levels varied according to their rates requirements being other costs were constant for each treatment.

In order to recommend the present results for the study area, it is necessary to estimate the minimum rate of return acceptable to farmers or producers in the recommendation domain. Based on partial budget analysis, the highest net benefit (46735 ETB ha ${ }^{-1}$ ) was obtained from treatment combination of variety Hidassie/large seed size/ with a seed rate of 300 seeds $^{-1}$, followed by net benefit ( 44460 ETB $\mathrm{ha}^{-1}$ ) was obtained from the treatment combination of variety Hidassie/large seed size/ with a seed rate of 250 seeds $/ \mathrm{m}^{-2}$, while the lowest net benefit (30117 ETB/ha ${ }^{-1}$ ) was also obtained from the combination of variety Hidassie/ large seed size/ with a seed rate of 400 seeds $/ \mathrm{m}^{-2}$ only in one growing season as shown on (Table 1) $[107,108]$.

\section{Benefit to Cost Ratio Analysis (BCR)}

The benefit-cost ratio analysis was used in the cost-benefit analysis in order to summarize the overall relationship between the relative costs and benefits of the proposed research project in which the BCR was expressed in monetary terms. The alternatives are not simply ranked but can be quantitatively assessed one against the other.

The highest benefit cost ratio of (7.57) with low marginal cost and more profitable MRR (795\%) was obtained from the variety Hidassie/large seed size/ at the use of 300 seeds $\mathrm{m}^{-2}$ seeding rate followed by (7.55) benefit cost ratio with the advantageous MRR (899\%) was recorded from the variety Hidassie/large seed size/ at seeding rate of 250 seeds $\mathrm{m}^{-2}$ respectively (Tables 1 and 2) [109,110].

\begin{tabular}{|c|c|c|c|c|c|c|c|c|}
\hline $\begin{array}{c}\text { Treatment } \\
\text { No }\end{array}$ & Variety & $\begin{array}{c}\text { Plant } \\
\text { Population } \\
\text { Ha-1 }\end{array}$ & $\begin{array}{c}\text { Average } \\
\text { Grain Yield } \\
\text { (kg ha-1) }\end{array}$ & $\begin{array}{c}\text { Adjusted } \\
\text { Grain Yield } \\
\text { (kg ha-1) }\end{array}$ & $\begin{array}{c}\text { Total Costs } \\
\text { that Varied } \\
\text { (ETB ha-1) }\end{array}$ & $\begin{array}{c}\text { Gross Farm } \\
\text { Benefit } \\
\text { (ETB ha-1) }\end{array}$ & $\begin{array}{c}\text { Net Benefit } \\
\text { Value (ETB } \\
\text { ha-1) }\end{array}$ & $\begin{array}{c}\text { Benefit to } \\
\text { Cost Ratio } \\
\text { (ET B) }\end{array}$ \\
\hline 1 & Shorima & 2500000 Seeds & 3930 & 3341 & 5382 & 43433 & 38051 & 7.07 \\
\hline 2 & Shorima & 3000000 Seeds & 4346 & 3694 & 5656 & 48022 & 42366 & 7.49 \\
\hline 3 & Shorima & 3500000 Seeds & 4322 & 3674 & 6001 & 47762 & 41761 & 6.96 \\
\hline 4 & Shorima & 4000000 Seeds & 4059 & 3450 & 6178 & 44850 & 38672 & 6.26 \\
\hline 5 & Dendea & 2500000 Seeds & 4134 & 3514 & 5595 & 45682 & 40087 & 7.16 \\
\hline 6 & Dendea & 3000000 Seeds & 4045 & 3438 & 5931 & 44694 & 38763 & 6.54 \\
\hline 7 & Dendea & 3500000 Seeds & 4485 & 3812 & 6236 & 49556 & 43320 & 6.95 \\
\hline 8 & Dendea & 4000000 Seeds & 4865 & 4135 & 6572 & 53755 & 47183 & 7.18 \\
\hline 9 & Hidassie & 2500000 Seeds & 4556 & 3873 & 5889 & 50349 & 44460 & 7.55 \\
\hline
\end{tabular}




\section{Journal of Ecology and Natural Resources}

\begin{tabular}{|l|l|l|l|l|l|l|l|l|}
\hline 10 & Hidassie & 3000000 Seeds & 4788 & 4070 & 6175 & 52910 & 46735 & 7.57 \\
\hline 11 & Hidassie & 3500000 Seeds & 3643 & 3097 & 6541 & 40261 & 33720 & 5.16 \\
\hline 12 & Hidassie & 4000000 Seeds & 3350 & 2848 & 6907 & 37024 & 30117 & 4.36 \\
\hline
\end{tabular}

Table 2: Partial Budgeting Analysis of Bread Wheat Grain Yields.

Note: Cost of seed 15.25 ETB per kg; Labor Cost ETB 35 per day; Field Sales price ETB 13.00 per kg

The changes to the variety Shorima at plant population levels of 250 seeds $\mathrm{m}-2$ is eliminated for this reason to remain with changes to the variety Hidassie/ at plant population levels of 250 and 300 seeds $\mathrm{m}^{-2}$ which gave more than $100 \%$
MRR as promising new practices for farmers under the prevailing price structure (Table 2). According CIMMYT, the minimum acceptable marginal rate of return (MRR) should be $100 \%$.

\begin{tabular}{|c|c|c|c|c|c|}
\hline Variety Seed Size and PPL & TVC (ETB/ha) & MC (ETB/ha) & NBV (ETB/ha) & MNB (ETB/ha) & MRR (\%) \\
\hline 1. Shorima/Small x 250 Seeds $\mathrm{m}-2$ & 5382 & & $8051^{*} \mathbf{E}$ & & \\
\hline 5. Dendea/Medium x 250 Seeds $\mathrm{m}^{-2}$ & 5595 & 213 & $0087 * \mathbf{E}$ & 2036 & 956 \\
\hline 2. Shorima/Small x 300 Seeds $\mathrm{m}^{-2}$ & 5656 & 61 & $2366 * \mathbf{E}$ & 2279 & 3736 \\
\hline 9. Hidassie/Large $\times 250$ Seeds $\mathrm{m}^{-2}$ & 5889 & 233 & 4460 & 2094 & 899 \\
\hline 10. Hidassie/Large $\mathrm{x} 300$ Seeds $\mathrm{m}^{-2}$ & 6175 & 286 & 6735 & 2275 & 795 \\
\hline 8. Dendea/Medium x 400 Seeds $\mathrm{m}^{-2}$ & 6572 & 397 & $7183^{*} \mathbf{E}$ & 448 & 113 \\
\hline
\end{tabular}

Table 3: Marginal Analysis Effects of Bread Wheat Grain Yield.

Note: ${ }^{*} \boldsymbol{E}=$ eliminated; $P P L=$ plant population level; $T V C=$ total variable cost; $N B V=$ net benefit value;

$M N B=$ marginal net benefit; $M R R=$ marginal rate of return .

As stated by CIMMYT, recommendation is not necessarily based on the highest yield and even not based on the highest MRR. Recommendation is just based on the highest net benefit cost ratio and thus, the most economically superior variety and seed rate for farmers of the study area with low cost of production and the highest net benefits were identified to be the variety Hidassie/large seed size/ at seeding rate of 300 seeds $\mathrm{m}^{-2}\left(142.00 \mathrm{~kg} \mathrm{ha}^{-2}\right)$. The seeding rate of 250 seeds $\mathrm{m}^{-2}\left(118 \mathrm{~kg} \mathrm{ha}^{-2}\right)$ of this variety was also profitable with the highest net benefit and recommended as $2^{\text {nd }}$ option. Consistent with the partial budgeting analysis results, it can be determined that the most profitable treatment was the variety Hidassie/large seed size/ which gave the highest benefit cost ratio of (7.57) and MRR (795\%) at seed rate of 300 seeds $\mathrm{m}^{-2}$ whereas, alternatively the MRR of $(899 \%)$ and benefit cost ratio (7.55) were attained also from the variety Hidassie/large seed size/ at seeding rate of 250 seeds $\mathrm{m}^{-2}$ [1], as shown on (Tables $2 \& 4$ ). Therefore, the changes to the variety Shorima/small seed size/ at a seed rate of 250 seeds $\mathrm{m}^{-2}$; Dendea/Medium seed size/ at a seed rate of 250 seeds $\mathrm{m}^{-2}$, Shorima/Small seed size/ at a seed rate of 300 seeds $\mathrm{m}^{-2}$ and Dendea/medium seed size/ at a seed rate of 400 seeds $\mathrm{m}^{-2}$ are eliminated for their low benefit cost ratio and to remain with the changes to the variety Hidassie/ large seed size/ at seed rate of 300 and 250 seeds $\mathrm{m}^{-2}$. The yield of treatment 8 is higher than that of treatment 10 as shown on (Table 2), but the dominance analysis shows that the value of the increase in yield is not enough to compensate the increase in costs. Farmers would be better off using the lower seed rate with lower costs [111].

\section{Conclusion and Recommendation}

All the recommendations which have suggested here in this paper are primarily addressed to the small scale farmers of the country as well as for all of other improved technology users in the country which are officially known under their agricultural development activities, are the focus this review paper in particular.

\section{Conclusion}

Bread wheat grown worldwide is popular for their numerous purposes in many countries including Ethiopia for many years. Bread wheat is of importance in many diets, on account of its nutritional significances and major economic and dietary importance to small-scale farmers. The productivity and area of most of the crops grown in many parts of Ethiopia are declining due to soil degradation and the constraints of moisture and nutrients unavailability together with it and other poor management and cultivation practices. However, farmers continue growing crops in spite of obtaining low yields as a result of having little choices as producing the crops are vital for meeting their nutritional 


\section{Journal of Ecology and Natural Resources}

and economic needs.

As a result, integrated soil fertility management is valuable to the plants for higher yield potential, seed quality and environment-friendly sustainable farming systems and increase of profit margins for growers along with good moisture maintaining in the growing soils. The existing findings of this review study shows that there is a need of important institutional and operational reforms for improving efficiency in the bread-wheat production. This paper has also reviewed wheat production practices and constraints in Ethiopia and hence, these constraints were broadly grouped into two categories: technical and socioeconomic. The two major bread wheat growing environments are:

- Highland cool wet areas and

- Low-altitude warm dry areas.

Even though there has been a reasonable extent of research to measure the influence of technical constraints on bread wheat production, research on socioeconomic constraints has mainly been qualitative. Therefore, there is a need to shift the emphasis of socio-economic research to quantitatively determine the impact of socio-economic constraints on wheat production. Agricultural research and technology generation has been an important aspect of government efforts for the development of Ethiopian agriculture. These include formal agricultural research and extension systems that have long been engaged in the generation, promotion and adoption of improved seeds and other farm technologies and management practices that potentially enhance wheat production and productivity. Some researchers reported that except in 2008 and 2009, local procurement of bread wheat would have been justified and provided better incentives for farmers to grow bread wheat at a higher price, which is still below import equivalence. This could encourage bread wheat producers to accept new technologies and increase bread wheat production.

\section{Recommendations}

As the research results of this study, the use of $125 \mathrm{~kg} / \mathrm{ha}$ seed rate for variety Dendea; $150 \mathrm{~kg} \mathrm{ha}^{-1}$ for varieties Shorima, Kekeba and $175 \mathrm{~kg} \mathrm{ha}^{-1}$ for variety Digalu can be recommend for most areas of Arsi zone as well as for interrelated areas of the same agro-ecological conditions. Moreover, depending on the agronomic performance and yield of different studies variety Shorima at $150 \mathrm{~kg} \mathrm{ha}^{-1}$ was advantageous. However, as this is one season and one location experiment, it has to be repeated over the wide-ranging agro-ecologies and seasons with consideration of cost of production to reach at conclusive recommendation.

Furthermore, the results of the reviewed experimental studies showed that using of different row spacing had no significant effect on parameters that have been taken except the plant height; however plant height, number of tiller per plant, spikelet per spike, grains per spike, biological yield, grain yield and straw were significantly affected by different seed rates. The interaction of seed rate \& row spacing also did not show significant difference except for the plant height.

According to the research results of Awtaro Woreda in Wolaita Zone, using of $75 \mathrm{~kg}$ seed $\mathrm{ha}^{-1}$ resulted in the maximum plant height $(83.87 \mathrm{~cm})$, number of tillers per plant (20.37) \& productive tillers per plant (2.30), however $100 \mathrm{~kg}$ seed $\mathrm{ha}^{-1}$ gave the highest biological yield $\left(7.98 \mathrm{t} \mathrm{ha}^{-1}\right)$, grain yield $\left(2.78 \mathrm{t} \mathrm{ha}^{-1}\right) \&$ straw $\left(5.27 \mathrm{tha}^{-1}\right)$.

But since the current results are gained from just one crop in some limited districts, conducting repetitive field experiments on different crops other than wheat at the wide-ranging of regions in the national level is suggested in order to confirm the current results on different crops \& in the entire farming lands of the country. According to the research results of Kulumsa, the economic analysis of the experiment was brought to select the best combination of the variety Hidassie/large seed size/at a plant population rate of 300 seeds $\mathrm{m}^{-2}\left(142.00 \mathrm{~kg} \mathrm{ha}^{-1}\right)$ gave the greatest grain yield (4070 kg ha-1) with low cost of production and higher net benefits and recommended tentatively as $1^{\text {st }}$ option for the study area. On the other hand, the variety Hidassie/large seed size/at a plant population rate of 250 seeds $\mathrm{m}^{-2}(118 \mathrm{~kg}$ ha $\left.{ }^{1}\right)$ gave better yield (3873 $\left.\mathrm{kg} \mathrm{ha}^{-1}\right)$ with a slightly additional cost rather than the primarily recommended seed rate and it has been recommended as a $2^{\text {nd }}$ option for the small scale farmers of the study area.

\section{References}

1. Anbessie D, Abebe M, Dechassa H (2020) Effect of Plant Population on Growth, Yields and Quality of Bread Wheat (Triticum aestivum L.) Varieties at Kulumsa in Arsi Zone, South-Eastern Ethiopia. IJRSAS 6(2): 32-53.

2. Akbar M, Muhammad T, Tayyab J, Muhammad A (2001) Evaluation of exotic wheat germplasm for seed yield and its components under rain fed conditions. Sarhad J Agric 17(4): 511-513.

3. Tunio SD, Korejo MN, Jarwar AD, Waggan MR (2006) Studies on indigenous and exotic weed competition in wheat. Pak J Agri Biol 5(4): 1-8.

4. Muhammad A, Gambo BA, Ibrahim ND (2011) Response of Onion (Allium cepa L.) to Irrigation Intervals and Plant Density in Zuru, Northern Guinea Savanna of Nigeria. Nigerian Journal of Basic and Applied Sciences 19(2): 241-247. 
5. IWMI Annual report (2010) Colombo, Sri Lanka: International Water Management Institute (IWMI). 28p. + Insert: 1 Book (IWMI celebrating 25 years of research achievements), 2 DVDs (IWMI Publications 1985-2010; IWMI@25: interviews with some past and present Board Chairs and Directors General).

6. GTP (2010) The Federal Democratic Republic of Ethiopia five years Growth and Transformation Plan. Growth and Transformation Plan, Addis Ababa, Ethiopia.

7. Jaleel CA, Manivannan P, Sankar B, Kishorekumar A, Gopi R, et al. (2007) Water deficit stress mitigation by calcium chloride in Catharanthus roseus; effects on oxidative stress, proline metabolism and indole alkaloid accumulation. Colloids Surf B Biointerfaces 60(1): 110116.

8. Cheruth AJ, Gopi R, Sankar B, Gomathinayagam M, Panneerselvam R (2008) Differential responses in water use efficiency in two varieties of Catharanthus roseus under drought stress. Comptes Rendus Biologies 331(1): 42-47.

9. Shock CC, Feibert EBG, Saunders LD (1998) Onion yield and quality affected by soil water potential as irrigation threshold. Hort Science 33(7): 1188-1191.

10. Liu W, Zhu D, Liu D, Geng M, Zhou W, etal. (2010) Influence of nitrogen on the primary and secondary metabolism and synthesis of flavonoids in chrysanthemum morifolium ramat. Journal of Plant Nutrition 33(2): 240254 .

11. Diriba-Shiferaw G (2016) Review of Management Strategies of Constraints in garlic (Allium sativum L.) Production. The Journal of Agricultural Sciences 11(3): 186-207.

12. Tisdale SL, Nelson WL (1985) Soil fertility and fertilizers, $3^{\text {rd }}$ (Edn.), Macmillan Publishing Co. Inc., New York and Collico-Macmillan Publishers, London.

13. Mattew LA, Wedell AN, Willium DP, John HP (2000) Micronutrient status. Agronomy Journal 92: 261-268.

14. Havlin JL, Beaton JD, Tisdale SL, Nelson WL (2007) An introduction to nutrient management. Soil Fertility and Fertilizers, pp: 244-289.

15. MoANR (2016) Crop Variety Register, Issue No. 19, Plant Variety Release, Protection and Seed Quality Control Directorate, Addis Ababa, Ethiopia.

16. (2003) Triticum species. Center for New Crops \& Plant Products, Purdue University.
17. CSA (2017) Agricultural sample survey: Report on area and production of major crops. (Private peasant holdings, Meher Season) Statistical Bulletin 584 Volume 1, Central Statistical Authority (CSA), Addis Ababa.

18. Malik MA, Irfan M, Ahmed ZI, Zahoor F (2006) Residual effect of summer grain legumes on yield and yield components of wheat (Triticum aestivum L.). Pak J Agri Agril Engg Vet Sci 22(1): 9-11.

19. Mann RA, Jehangir WA, Masih I (2004) Improving crop and water productivity of rice-wheat system in Punjab, Pakistan. In: Proceedings of the 4th International Crop Science Congress, Brisbane.

20. Anonymous (2002) Nutrient Deficiency Symptoms in Rice. Better Crops Intl. The Journal of Agricultural Sciences 11: 3198.

21. Almaz A (2014) Response of Sulphur Fertilizer Application to Growth, Yield and Quality of Bread Wheat (Triticum Aestivum) in Kulumsa, Arsi, Ethiopia.

22. Shewry PR, D’Ovidio R, Lafiandra D, Jenkins JA, Mills ENC, et al. (2009) Wheat Grain Proteins. In: Khan K, Shewry PR, (Eds.), Wheat. St. Paul, AACC International, Inc.

23. Slukova M, Levkova J, Michalcova A, Horackova S, Skrivan $P$ (2017) Effect of the Dough Mixing Process on the Quality of Wheat Buckwheat Proteins 35(6): 522-531.

24. Pena-Bautista RJ, Hernandez-Espinosa N, Jones JM, Guzman C, Braun HJ (2017) CIMMYT Series on Carbohydrates, Wheat, Grains, and Health: Wheat-Based Foods: Their Global and Regional Importance in the Food Supply, Nutrition, and Health.

25. Braun H-J, Atlin G, Payne T (2010) Multi-location testing as a tool to identify plant response to global climate change. In: Climate change and crop production (ed. M.P. Reynolds). CABI International, pp: 115-138.

26. Shiferaw B, Smale M, Braun HJ, Duveiller E, Reynolds M, et al. (2013) Crops that feed the world 10. Past successes and future challenges to the role played by wheat in global food security. Food Security 5(3): 291-317.

27. Braun HJ, Saulescu NN (2002) Breeding winter and facultative wheat. In: Curtis BC, Rajaram S, Macpherson HG, (Eds.), Bred wheat, Improvement and production, pp: 567-575.

28. FAOSTAT (2011) Food and Agriculture Organization of the United Nations Statistics.

29. CSA (2014a) Agricultural Sample Survey. Volume: Report on Area and Production of Major Crops. Addis Ababa. 
30. EEA (2015) Report on the Ethiopian Economy. Ethiopian Economics Association, Addis Ababa, Ethiopia.

31. Minot N, Warner J, Lemma S, Kassa L, Gashaw A, et al. (2015) The Wheat Supply Chain in Ethiopia: Patterns, Trends, and Policy Options. International Food Policy Research Institute (IFPRI) Washington, DC.

32. FAO (2015a) Food Balance Sheets. FAOSTAT, Rome.

33. Bergh K, Chew A, Gugerty MK, Anderson L (2012) Wheat Value Chain: Ethiopia: Study conducted for the Agricultural Policy Team of the Bill \& Melinda Gates Foundation. EPAR.

34. FAO (2014) Analysis of price incentives for wheat in Ethiopia for the time period 2005-2012. FAO/the Monitoring and Analysing Food and Agricultural Policies (MAFAP) programme, Rome, Italy.

35. Jeffrey W, Tanner DG, Corbett JD (2001) An AgroClimatological Characterization of Bread Wheat Production Areas in Ethiopia. NRG-GIS Series 01-01, CIMMYT, Mexico, D.F.

36. CorbettJD, O'Brien RF (1997)TheSpatialCharacterization Tool. Texas Agricultural Experimental Station, Texas A\&M University System, Blackland Research Center, CDROM, College Station, Texas A\&M University.

37. Campbell CA, Myers RJK, Curtin D (2004) Managing nitrogen for sustainable crop production. Earth and Environmental Science 42(1-3): 277-296.

38. Ryan J (2008) A Perspective on balanced fertilization in the Mediterranean Region. Turkish Journal of Agriculture and Forestry 32: 79-89.

39. Chien SH, Menon G (1995) Agronomic evaluation of modified phosphate rock products. Fertilizer Research 41: 197-205.

40. Marschner H (1995) Mineral Nutrition of Higher Plants, 2nd (Edn.), Harcourt Brace and Company: 889, Academic Press, London.

41. Rao MR, Kwesiga NA, Duguma FB, Frazel S, Jama B, et al. (1998) Soil fertility Replenishment in Sub-Saharan Africa. In: Agro forestry today (Debra London Ed.) International Center for Research in Agro forestry (ICRAF) UK 10(2): 2-5.

42. Yohannes U (1994) The effect of nitrogen, phosphorous, potassium, and sulphur on the yield and yield components of Enset (Ensete ventricosum W.) in southeast Ethiopia. Doctoral dissertation. Institute of
Plant nutrition, Faculty of Agriculture. Justus Liebig University, Giessen, Germany.

43. Asnakew W, Tekalign M (1991) Soil fertility management studies on wheat in Ethiopia. Debre Zeit Agricultural Research Center, Ethiopia: 137-173.

44. Berga L, Gebremedhin W, Terrisa J, Bereke-Tsehai T, Yaynu H (1994) Potato Improvement Research. In: Herath E. and D. Lemma (eds.). Proceedings of the Second National Horticultural Workshop of Ethiopia, Institute of Agricultural Research and Food and Agriculture Organization, Addis Ababa, Ethiopia.

45. Cantwell M, Voss R, Hanson B, May D, Rice B (2006) Water and Fertilizer management for Bread Wheat: Productivity, Nutrient and Water Use Efficiency, and Post-Harvest Quality. Report of a FREP Contact No. 970207.

46. Gubb IR, Tavis MSH (2002) Onion pre-harvest and postharvest considerations. In: Rabinowitch HD \& Currah L (Eds.), Allim Crop Science, CABI publishing, UK, pp: 237-250.

47. Biswas TD, Mukherjee SK (1993) Textbook of Soil Science, $5^{\text {th }}$ (Edn.), Tata McGraw-Hill, New Delhi, pp: 170-197.

48. Raun WR, Johnson GV (1999) Improving nitrogen use efficiency for cereal production. Agronomy Journal 91(3): 357-363.

49. Good AG, Shrawat AK, Muench DG (2004) Can less yield more? Is reducing nutrient input into the environment compatible with maintaining crop production. Trends Plant Sci 9(12): 597-605.

50. Morris M, Kelly VA, Kopicki RJ, Byelee D (2007) Fertilizer Use in African Agriculture: Lessons Learned and Good Practices Guidelines. World Bank, Washington, DC.

51. Demere E, Gebrekidan H (2008) Economic Application Rates of Nitrogen and Phosphorus Fertilizers' for Maize Grown on Black Clay Soil (Vertisols) of Alemaya Areas, Ethiopia. Ethiopian Journal Agricultural Economics 7(1): 108-121.

52. Tesfaye A, Githiri M, Dereraand J, Debele T (2011) Subsistence farmers' experiences and perceptions about soil and fertilizer use in western Ethiopia. Journal of Applied Science and Technology 2(2): 61-74.

53. Vlek PLG (1990) The role of fertilizers in sustaining agriculture in sub-Saharan Africa. Fertilizer Research 26: 327-339. 
54. Murage EW, Karanja NK, Smithson PC, Woomer PL (2000) Diagnostic indicators of soil quality in productive and non-productive smallholders' fields of Kenya's Central Highlands. Agriculture, Ecosystems and Environment 79(1): 1-8.

55. Kakar AA, Abdullahzai MK, Saleem M, Qaim Shah SA (2002) Effect of Nitrogenous Fertilizer on Growth and Yield of Bread Wheat. Asian Journal of Plant Sciences 1(5): 544-545.

56. Bodnar J, Schumacher B, Uyenaka J (1998) Bread Wheat Production. Agricultural and Rural Division. Davis, California, USA.

57. Potgieter J (2006) Verbal communication on macroelements application time. Department of Agriculture, Researcher, Limpopo.

58. Stork PO, Potgieter JP, Van Den Heever E, Niederwieser JG (2004) Garlic Production, Guide to Garlic Production in South Africa, Agricultural Research Council- Vegetable and Ornamental Plant Institute, Roodeplaat, Pretoria.

59. Batal KM, Bondari K, Granberry DM, Mulinix BG (1994) Effects of source, rate and frequency of $\mathrm{N}$ application on yield, marketable grades and rot incidence of sweet onion Allium L.C. Granex 33. Journal of Horticultural Science 69(6): 1043-1051.

60. Bachmann J (2001) Organic Garlic Production. National sustainable agriculture information service, Davis, California, USA.

61. Fikreyohannes G (2005) Effect of Clove Size and Plant Density on the Bulb Yield and Yield Components of Garlic (Allium sativum L.) in Awabel Woreda, Eastern Gojjam Zone. M.Sc. Thesis Submitted to School of Graduate Studies of Alemaya University, Ethiopia, pp: 19-41.

62. Kilgori MJ, Magaji MD, Yakubu AI (2007) Productivity of two Galrik (Allium sativum L.) Cultivars as Affected by Different Levels of Nitrogenous and Phosphorus Fertilizers in Sokota, Nigeria. American-Eurasian Journal of Agricultural \& Environmental Sciences 2(2): 158-162.

63. Babaji BA (1994) Effect of plant spacing and nitrogen fertilization on growth and yield of Garlic. An M.Sc. Thesis submitted to the Post-Graduate School.

64. Barber SA (1995) Soil nutrient bioavailability. A mechanistic approach. John Wiley \& Sons, New York.

65. Norman M, Rearsonand C, Searle P (1995) The Ecology of Tropical Food Crops. Cambridge University Press, Cambridge.
66. Fairhust T, Lefroy R, Mutert E, Batjes N (1999) The importance, distribution and causes of phosphorus deficiency as a constraint to crop production in the tropics. Agroforestry Forum 9: 2-8.

67. Miller RW, Donanue RL (1995) Soils in our environment, $7^{\text {th }}$ (Edn.), Prentice Hall, Englewood cliff, pp: 261-281.

68. McPharlin IR, Robertson WJ (1999) Response of onions (Allium cepa L.) to phosphate fertilizer placement and residual phosphorus on a Karrakatta sand. Australian Journal of Experimental Agriculture 39(3): 351-359.

69. Greenwood DJ, Stone DA, Barnes A (2001) Root development of vegetable crops. Plant and Soil 68: 7596.

70. Alt D, Ladebusch H, Melzer O (1999) Long-term trial with increasing amounts of phosphorus, potassium and magnesium applied to vegetable crops. Acta Horticulture 506: 29-36.

71. Pire R, Ramirez H, Riera J, Gomez TN (2001) Removal of N, P, K and Ca by an onion crop (Allium cepa L.) in a silty-clay soil, in a semiarid region of Venezuela. Acta Horticulturae 555: 103-109.

72. Salo T, Suojala T, Kallela M (2002) The effect of fertigation on yield and nutrient uptake of cabbage, carrot and onion. Acta Horticulturae 571: 235-241.

73. Jamma B (1998) Soil Fertility Replenishment Initiatives in Western Kenya: Soil Fertility Management Workshop.

74. Sims WL, Davis UC, Little TM, Emeritus A, Voss RE (2003) Growing Garlic in California. UC Davis, Vegetable Research and Information Center.

75. Alaam SM, Latif A, Zafar I (2002) Wheat yield and phosphorus use efficiency as influenced by method of phosphorus and zinc application. Pakistan Journal of Scientific and Industrial Research 45: 117-119.

76. Ezekiel AA, Adigun IO (2005) Phosphorus-use Efficiency by Pepper (Capsicum frutescens) and Okra (Abelmoschus esculentum) at Different Phosphorus Fertilizer Application Levels on Two Tropical soils. Journal of Applied Sciences 5(10): 1785-1791.

77. Brewster JL (1987) The effect of temperature on the rate of sprout growth and development within stored onion Bulbs. Annals of Applied Biology 111(2): 463-465.

78. Lemma D, Herath E (1994) Agronomic Studies on Allium. Pp.139-145. In: Horticultural Research and Development in Ethiopia. 1-3 December 1992. Institute of Agricultural research and food and Agricultural Organization. Addis 


\section{Journal of Ecology and Natural Resources}

Ababa, Ethiopia.

79. Murashkina M, Southard RJ, Pettygrove GS (2006) Potassium Fixation in Silt, Sand and Clay Fractions of Soils Derived from Granitic Alluvium of the San Joaquin Valley, California. The 18th World Congress of Soil Science at Philadelphia, Pennsylvania, USA.

80. Lujiu L, Xisheng G, Qingsong Z, Hongmin $X$, Lin $Z$ (2004) Balanced Fertilization Increases Garlic Yield in Anhui. Better Crops 88(4): 3035.

81. Zhou Y, Wang D, Zhu J, Liu Q, Fan MX (2005) The role of sulfur fertilizers in balanced fertilization. In: De Kok LJ, Schnug E (Eds.), Proceedings of the $1^{\text {st }}$ Sino-German Workshop on Aspects of Sulphur Nutrition of Plants, 2327 May 2004 in Shenyang, China, Land bauforschung Völkenrode 283: 171-176.

82. Fan MX, Messick DL (2007) Correcting Sulphur Deficiency for Higher Productivity and Fertilizer Efficiency. IFA Asia-Pacific Crossroads in Bali, The Sulphur Institute (TSI), United States.

83. Jaggi RC, Raina SK (2008) Direct, residual and direct + residual effects of sulphur in Bread Wheat (Allium sativum L) - maize (Zea mays) cropping sequence. Journal of Environmental Biology 29(1): 85-88.

84. Surendra S (2008) Effect of sulphur on yields and S uptake by onion and Bread Wheat grown in acid alfisol of Ranchi. Agricultural Science Digest 28(3): 189-191.

85. Palm CA, Myers RJK, Nandwa SM (1997) Combined use of organic and inorganic nutrient source for soil fertility maintenance and replenishment. In: Buresh et al., (Eds.). Replenishing soil fertility in Africa. Special publication No. 51. Wisconsin, USA, pp: 193217.

86. Shalini SB, Channal HT, Hebsur NS, Dharmatti PR, Sarangamath PA (2002) Effect of integrated nitrogen management on nutrient uptake in Knolkhol, yield and nutrient availability in the soil. Karnataka Journal of Agricultural Sciences 15(1): 43-46.

87. Harendra S, Kumar SM, Singh KV (2009) Effect of Sulphur and FYM on Yield and Nutrients Uptake by Garlic (Allium sativum L.) in an Alluvial Soil. Annals of Horticulture 2(1): 86-88.

88. Alam MN, Abedin MJ, Azad MAK (2010) Effect of micronutrients on growth and yield of onion under calcareous soil environment. International Research Journal of Plant Sciences 1(3): 56-61.

89. Islah M El-Hifny (2010) Response of Garlic (Allium sativum L.) to some Sources of Organic Fertilizers under North Sinai Conditions. Research Journal of Agriculture and Biological Sciences 6(6): 928-936.

90. IWMI (2010) Irrigation potential in Ethiopia; Constraints and opportunities for enhancing the system. International Water Management Institute.

91. Shrestha H (2007) A plant monograph on onion (Allium cepa L.). The School of Pharmaceutical and Biomedical Sciences, Pokhara University Simalchaur, Pokhara, Nepal.

92. Fisseha G (1983) The effects of alternative sources of organic fertilizers in increasing the yield of onions (Allium cepa L.). An M.Sc. Thesis presented to School of Graduate Studies of Addis Ababa University, Ethiopia, pp: 30-70.

93. Baligar VC, Fageria NK, He ZL (2001) Nutrient Use Efficiency in Plants. J Comm Soil Sci Plant Analysis 32(7): 921-950.

94. Ruthford PP, Whittle R (1982) The carbohydrate composition of onions during long-term cold storage. The Journal of Horticultural Science 57(3): 349-356.

95. Randle WM, Lancaster JE (1995) Quantifying onion flavor compounds responding to sulphur fertility, sulphur increases level alk(en)yl cysteine sulfoxides and biosynthetic intermediates. American Society for Horticultural Science 120(6): 1075-1081.

96. Jones RN (1990) Cytogenetics. In: Rabinowitch, H.D., and Brewster, J.L. (eds.), Onions and Allied Crop Volume 1. Botany, Physiology and Genetics CRC Press, Inc. Boca Raton, Florida, pp: 103-124.

97. Cantwell MI, Kang J, Hong G (2003) Heat treatments control sprouting and rooting of Bread Wheat cloves. Postharvest Biology and Technology 30: 57- 65.

98. Davis HR, Isenberg MR (1978) Storage recommendation for northern grown onions. The Journal of Agricultural Sciences, Cornell university extension bulletin No. 148 . Ithaca, New York, 11(3200): 214.

99. Satti SME, Lopez M (1994) Effects of Storage Temperature on Growth and Bulb Formation in four Garlic (Allium sativum L.) Cultivars. Pakistan Journal of Botany 26(1): 161-165.

100. Anonymous (2004) GARLIC (organic)- Allium sativum, Factsheet, Ministry of Agriculture, Fisheries and Food Industry Competitiveness Branch, British Columbia, pp: 1-12.

101. Gobena N, Anbessie Debebe, Amare T, Mengistu 
C, Dugasa G, et al. (2019) Determination of the Rate of Rhizobial Bio fertilizers for Faba Bean ( $V$. faba), in the Major Growing Areas of Arsi Zone. Journal of Biology Agriculture and Healthcare 9(21): 29-36.

102. Saritha M, Prasad Tollamadugu NVKV (2019) The Status of Research and Application of Biofertilizers and Biopesticides: Global Scenario. In: Buddolla V (Edn.), Recent Developments in Applied Microbiology and Biochemistry, Academic Press.

103. Fisher K, Newton WE (2002) Nitrogen Fixation- A General Overview. In: Jeffery Leigh G, (Ed.), Nitrogen Fixation at the Millenniu, Elsevier.

104. CSA (2013) Agricultural Sample Survey 2006-07: Report on Area and Production of Crops, Addis Ababa, Ethiopia.

105. Salama AM, Hicks JR, Nock JF (1988) Respiration and fresh weight of onion bulbs as affected by storage temperature, humidity and maleic hydrazide. The Journal of Tropical Forest Science 27(4): 233-238.

106. Salomon R (2002) Virus diseases in Bread Wheat and the propagation of virus free planting. In:
Rabinowitch HD, Currah L, (Eds.), Allium crop sciences: Recent advances, CAB International, Wallingford, UK, pp: 311327.

107. Samuel G (1981) Uptake and Response of Durum Wheat (Triticum durum. Desf) to $\mathrm{N}$ and P Fertilization on Koticha and Gombore Soils of Ada'a Plains. An M.Sc. Thesis Submitted to College of Agriculture, Alemaya University, Ethiopia, pp: 98.

108. Singh SP, Verma AB (2001) Response of onion (Allium cepa L.) to potassium application. Indian Journal of Agronomy 46(1): 182-185.

109. Tilahun H, Teklu E, Michael M, Fitsum H, Awulachew SB (2011) Comparative Performance of Irrigated and Rain-fed Agriculture in Ethiopia. World Applied Sciences Journal 14(2): 235-244.

110. Tisdale SL, Nelson WL, Beaton JD, Halvin JL (1993) Soil Fertility and Fertilizers, $5^{\text {th }}$ (Edn.), Macmillan Publishing Company, New York.

111. Zahid Pervaiz, Khadim H, Gill SSH, Sheikh AA (2003) Iron requirement of Barani wheat. Int J Agri Biol 5(4): 608-610. 